Journal of Thermal Engineering, Vol. 7, No. 4, pp. 970-983, May, 2021

Yildiz Technical University Press, Istanbul, Turkey

\title{
SOLAR ABSORPTION COOLING SYSTEMS: A REVIEW
}

\author{
Ali Abdulqader Mustafa ${ }^{1}$, Zamri Noranai², Ahmed Abdulnabi Imran ${ }^{3}$
}

\begin{abstract}
Reduction of the green-house effect can be obtained by reducing the emissions of $\mathrm{CO}_{2}$. One of the technologies that contributes to this purpose is using solar cooling systems. An example of such systems is Lithium Bromide Absorption Chillers-Driven by Hot Water $\left(\mathrm{LiBr} / \mathrm{H}_{2} \mathrm{O}\right.$ absorption chillers). These chillers are normally powered by solar collectors (ordinary plate or evacuate tubular), which are widely accessible. This paper includes a review of previous experimental and theoretical studies on the effect of single cooling absorption systems. In addition, new proposals regarding the design of the solar collectors, supporting systems for energy and cooling methods will be provided. Furthermore, the present paper also summarizes the major double influence of the cooling absorption systems, add to the two-stage and half-effect absorption coolers. The influence of double cooling absorption systems using solar power could be considered for the buildings with more cooling capacity requirements, but with structure of space restrictions. However, for these cases is important to consider the direct irradiation, which needs high levels. For dry regions with water shortage, half-absorption and two-stage absorption coolers are more suitable. Solar-powered cooling systems designs should follow and incorporate standard rules based on the characteristics of various areas in order to be applicable on a large scale.
\end{abstract}

\section{Keywords: Solar Cooling, Absorption Cooling, Saving Power, Solar Power}

\section{INTRODUCTION}

A source of heat (e.g., solar energy, heat dissipation from manufactory, direct heat from heating equipment) is needed to supply the necessary power for operating the cooling equipment. The absorption cooling is the most popular method compared with pressure cooling when electricity is not available, expensive or not required, and also when the inconvenience caused by compressors is problematic [18]. Both absorption cooling system and compression cooling systems are cooled at low boiling point. In both types, when the cooling fluid evaporates, some heat is released out to provide a feeling of cooling. The main difference between them is in the cooling fluid - the liquid in the absorption cooling system changes that from gaseous state and returns to the liquid state. In the compression cooling system, the cooling fluid changes from liquid state to the gaseous state. The other difference is the type of cooling fluid. For the absorption cooling system, water or ammonia is used, while the compression cooling system uses chlorofluorocarbons [21]. The absorption-cooling circuit can be explained in the three stages as show in Fig. 1.

1. Evaporation: cooling fluid is calculated in a low-pressure environment (low partial pressure) and thus conveys heat from the "evaporator" environment

2. Absorption: absorbed refrigerants degraded "mixed" with another fluid - to reduce their pressure in the evaporator and to bring in a quantity of fluids to evaporate.

3. Renewal of the cooling cycle: the cooling fluid is heated and evaporated and then condensates by a heat exchanger. In order to renew the cooling cycle in the evaporator, pressure is applied in the evaporator to bring in a quantity of fluids to evaporate.

This paper was recommended for publication in revised form by Regional Editor Jovana Radulovic

${ }^{I}$ Mechanical Engineering Department, University Tun Hussein Onn (UTHM)- Malaysia.

${ }^{2}$ Mechanical Engineering Department, University Tun Hussein Onn (UTHM)- Malaysia. E-mail address:

${ }^{3}$ Mechanical Engineering Department, University of Technology-Iraq.

E-mail address: Dr.tota.k.turkan@gmail.com,zamrin@uthm.edu.my,10601@uotechnology.edu.iq

Orcid id:0000-0002-2647-2909

Manuscript Received 15 April 2019, Accepted 21 August 2019 


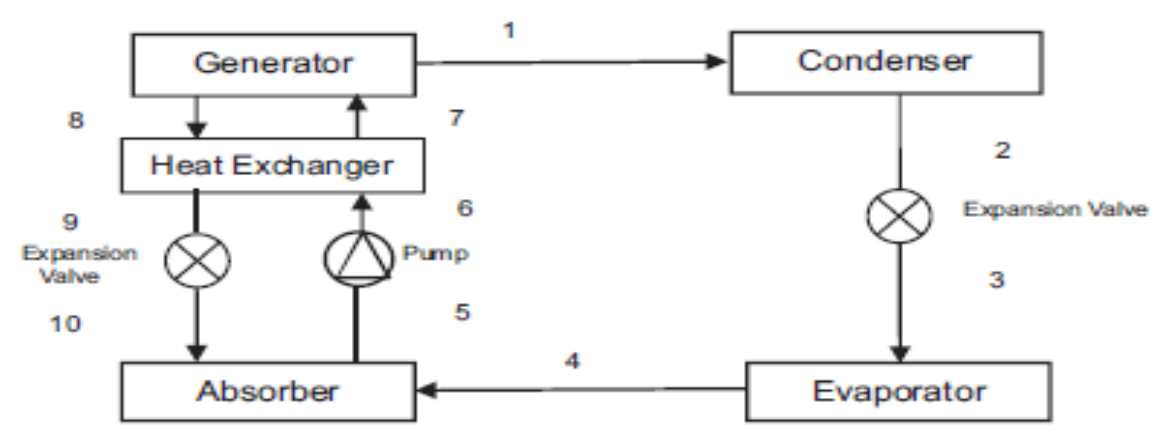

Figure 1. $\mathrm{LiBr}-\mathrm{H}_{2} \mathrm{O}$ absorption equipment. [ from AL-UGLA et al.[3],with permission from Elsevier.]

Table 1. Main operating parameters of the existing solar-powered single-effect absorption cooling systems

\begin{tabular}{|c|c|c|c|}
\hline Fluid & $\begin{array}{c}\text { Operating } \\
\text { temperature/ } / \text { C }\end{array}$ & COP & $\begin{array}{c}\text { Solar collecting } \\
\text { efficiency }\end{array}$ \\
\hline Hot-Water & $65-100$ & & \\
\hline Chilled-Water & $7-15$ & $0.33-0.70$ & $35 \%-50 \%$ \\
\hline Cooling-Water & $26-32$ & & \\
\hline
\end{tabular}

\section{SOLAR-POWERED ABSORPTION COOLING SYSTEMS}

\section{Theoretical Studies}

Evangelos and Christos [15] The cost and performance of solar cooling fan has been investigated for a $100 \mathrm{~m}^{2}$ building in ten different cities around the world including Abu Dhabi, Phoenix, Tehran, Cairo, Athens, Almeria, Thessaloniki, Madrid, Rome and Istanbul. The analysis was conducted via TRANSIS. The solar refrigeration unit consisted of $\mathrm{LiBr}-\mathrm{H}_{2} \mathrm{O}$, evacuated tube and storage tank. Simulation result showed Abu Dhabi and the city of Phoenix most cities are suitable for the work of refrigeration unit solar absorber and the minimum cost was 0.0575 and 0.0590 , respectively. While Rome, Madrid and the Thessaloniki are less appropriate and cost 0.1771 and 0.1792 and 0.2125 , respectively. In addition to this, the results have considered the sites that contain high solar energy are the best sites suitable for the work of solar refrigeration units.

Al ugla et al. [3] compared three type of air conditioning systems. These are "a conventional vaporcompression system", a solar $\left(\mathrm{LiBr} / \mathrm{H}_{2} \mathrm{O}\right)$ absorption system and "a solar photovoltaic (pv) vapor-compression system". The study was applied in Khobar city, Saudi Arabia on a large building, using techno-analysis. The study aimed at reducing the power supply in order to obtain constant cooling throughout the day. Moreover, to identify the economic advantages of the solution. The results showed that the solar absorption system is more beneficial than the vapor compression system, the (pv) vapor compression system has a payback period of 23.9 years, versus 18.5 years for the solar absorption and the COP was improved through reducing the running temperature of the condenser and increasing the running temperature of the evaporator, which have positive economic impact for the solar absorption system.

Amine Allouhi et al. [4] evaluated solar absorption cooling technologies under weather conditions in Morocco based on the characteristics of the Moroccan modern house. The simulation tool used was TRANSOL and the data included meteorological information from various climate for six zones. The simulations results are indicated significant energy saving and $\mathrm{CO}_{2}$ reduction with the application of solar-powered cooling systems in the modernistic houses in Morocco. Regarding the economic feasibility, the study indicated that the costs of the initial placing determine an extensive period of payback. Thus, in the present Moroccan situation, the implementation of such systems is not viable. In order to implement solar-powered cooling systems, it is needful to reduce the price of 
various components. The study also presents other obstacles of such implementation, namely technological, financial, institutional and even behavioral limits.

Al- Alili et al. [5] investigated the possibility to increase the solar fraction and the functioning into night time by applying different system configurations and new combinations of refrigerants and absorbents. The parameters applied are: normalized collector area $\left(4.67 \mathrm{~m}^{2} \mathrm{~kW} /{ }^{\circ} \mathrm{C}\right)$, normalized thermal storage $\left(0.21 \mathrm{~m}^{3} \mathrm{~kW} /{ }^{\circ} \mathrm{C}\right)$, coefficient of performance $(0.68)$ and average temperature of regeneration $\left(88.58{ }^{\circ} \mathrm{C}\right)$.

The study of Fasfous et al. [16] analyzed the possibilities of improving the quality of the indoor air by using a solar powered cooling system. The analyzed space was a laboratory of the Jordan University, in Amman, at Mango Center for Scientific Research. The space parameters are area $41 \mathrm{~m}^{2}$ and height $3.65 \mathrm{~m}$. The measurements included the hourly ambient temperature and the monthly value of radiation. The conclusions of the study indicated that the 40 $\mathrm{m}^{2}$ solar collector is not sufficient to power the air conditioning $(8 \mathrm{~kW})$, hot water (up to $\left.100 \%\right)$ and heating $(15-25 \%$ solar) systems. The predestined period of payback 24 years for the system cooling powered by the solar is longer than the duration of the project. The results showed that the implementation of the project is not suitable under current investment conditions.

Bani Younes et al. [10] investigated the subtropical climate in Queensland in three locations (Rockhampton, Gladstone and Emerald). The type of building analyzed was an office building equipped with a solar absorption system. The simulation was performed using TRNSYS16 and covered the summer seasons, which are from September to April. The maximum radiation and temperature for each location are $\left(400 \mathrm{~W} / \mathrm{m}^{2}\right)$ and $\left(35{ }^{\circ} \mathrm{C}\right)$. For the system in Emerald, $\left(50 \mathrm{~m}^{2}\right)$ area of collector and $(0.3 \mathrm{~m} 3)$ volume of storage water save up to $73 \%$ energy; when using a $1.8 \mathrm{~m} 3$, the energy saving increases to $88 \%$ as show in Fig. 2. For the system in Gladstone, a $50 \mathrm{~m}^{2}$ solar collector and a $0.3 \mathrm{~m}^{3}$ of water storage produce a $69 \%$ energy saving, which can be increased to $82 \%$ when using a $1.8 \mathrm{~m} 3$ hot-water storage tank as show in Fig. 3. For the system in Rockhampton, a $50 \mathrm{~m}^{2}$ solar collector and a $0.3 \mathrm{~m}^{3}$ of water storage produce a $62 \%$ energy saving, which can be increased to $80 \%$ when using a $1.8 \mathrm{~m}^{3}$ hot water tank as show in Fig. 4.

Emerald

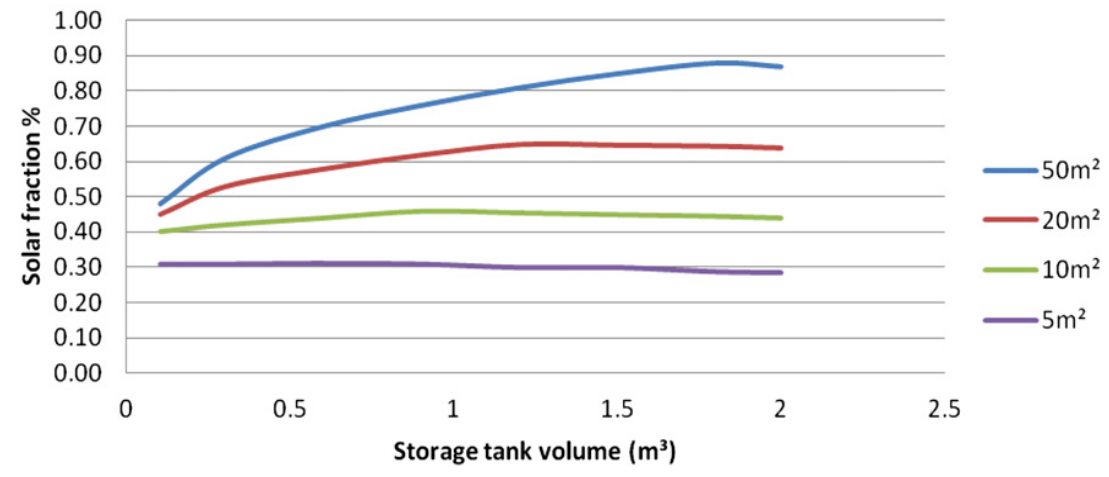

Figure 2. "Hot water tank influence on the annual solar fraction Emerald. [from Baniyounes et al.[10], with permission from Elsevier.] "

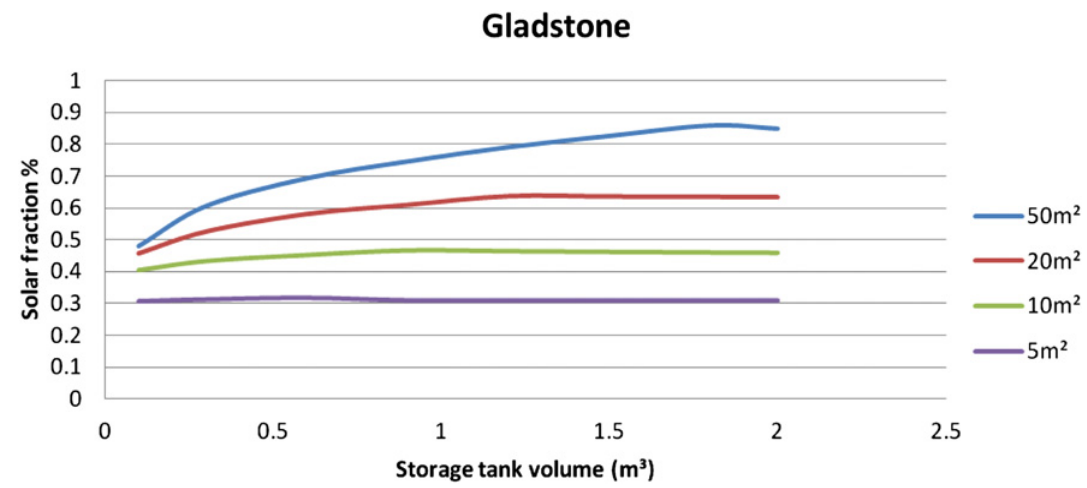

Figure 3. "Hot water tank influence on the annual solar fraction Gladstone [from Baniyounes et al.[10], with permission from Elsevier.] " 


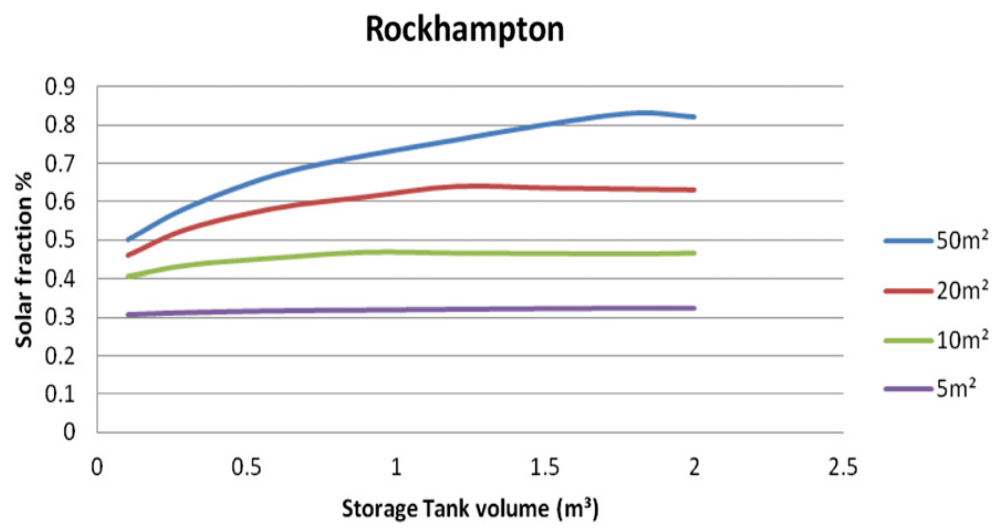

Figure 4. "Hot water tank influence on the annual solar fraction Rockhampton [from Baniyounes et al.[10], with permission from Elsevier.] "

The study Ullah et al. [50] includes a review of various solar thermal refrigeration systems, focusing on solar absorption cooling systems with different working liquids. Various combinations are presented according their performance levels, minimum and maximum functioning temperatures and cooling power capabilities.

Farshi et al. [18] focused on double effect absorption cooling systems. In terms of cost, the exergoeconomic analysis performed showed that evaporator and generator high temperatures, condenser low temperatures and low effectiveness of the heat exchanger have good results cost wise. The techno-economic analysis indicated that solar electric (PV) cooling systems are less recommended than solar absorption systems. There are Several factors indicates on their impact on solar absorption systems, such as location, weather conditions, components prices, cooling load, design of the system and performance. This study is the first analysis on a commercial building situated in Khobar city, eastern Saudi-Arabia and it analyzes the possibility of implementing solar air-conditioning systems in such conditions.

Jelinek et al. [25] experimented with the replacement of the jet ejector with a mixer that mixes the absorbent with the compressed cooling gas and a mechanical compressor that increases the pressure of the cooling gas. The experimental data was compared with the original design. leading the results showed that the new compressor-mixer reduced necessary generator temperature and circulation ratio and reduced volume of the heat exchanger but increased COP. The drawback of the proposed system is increase the power consumption.

Al-Alili [6] focused $10 \mathrm{~kW}^{\circ} \mathrm{C} \mathrm{NH} \mathrm{N}_{3} / \mathrm{H}_{2} \mathrm{O}$ absorption cooler, with a $6 \mathrm{~m}^{2} \mathrm{~kW}^{\circ} \mathrm{C}^{-1}$ area and $0.1 \mathrm{~m}^{3} \mathrm{~kW}^{\circ} \mathrm{C}^{-1}$ volume tank, under the weather conditions in Abu Dhabi. The study followed the economic and environmental advantages of the system, as well as its performance. The results indicated a $47 \%$ lower power consumption, compared with the vapor compression cycle for the same conditions. The initial investment as a very important aspect in reducing the payback period.

Eicker et al. [16] used dynamic simulation models for a single effect solar absorption system to analyze various alternatives of heat ejection. The cooling parameters were applied from a $15 \mathrm{~kW}$ solar absorption cooler. The possible ejection methods were dry and wet cooling towers and geothermal heat rejection systems. The lowest power consumption was recorded for the geothermal heat rejection systems, $30 \%$ lower than the best scenario for wet cooling towers with controlling the frequency of all the elements.

Praene et al. [38] designed a $(30 \mathrm{~kW}) \mathrm{LiBr} / \mathrm{H}_{2} \mathrm{O}$ single effect absorption cooling system. The system was installed at the University Institute of Technology from Saint- Pierre and tested in a classroom. The results indicated that comfort temperature can be achieved at $20 \mathrm{~kW}$, using water tanks for storage of cold and hot water. In order to produce $30 \mathrm{~kW}$, the solar loop needs to be further improved.

The solar cooling system analyzed by Monne et al. [35] was a $(4.5 \mathrm{~kW}) \mathrm{LiBr} / \mathrm{H}_{2} \mathrm{O}$ single effect rotary absorption cooling, with $\left(37.5 \mathrm{~m}^{2}\right)$ flat plate collectors and a cooling tower. The data was collected for the years 2007 and 2008. The COP for the cooling power recorded in 2007 was $0.6 \mathrm{~kW}$ and $(0.46-0.56) \mathrm{kW}$ for 2008. Also, the 
values for the chiller were between (4 - 5.6) kW for 2007 and (3.6 - 5.3) $\mathrm{kW}$ in 2008. Hang et al. (2011) analyzed on a middle-size office building in California. The cooling system included a (4.5) $\mathrm{kW}$ single influence absorption chiller, a gas powered secondary heater, evacuated tube solar collector and a storage tank for hot fluid (water). The results showed that a balance between economic, environmental and energetic performances of the system. No significant power savings were achieved in any of the configurations. However, the $\mathrm{CO}_{2}$ emissions is reduced by $80 \%$ with the implementation of the solar collector. The volume of the water storage-tank influences the execution of the system. The best results are obtained for a 0.02-0.04 volume to area ratio. The optimal parameters for the system are: $280 \mathrm{~m}^{2}$ collector area, $11 \mathrm{~m}^{3}$ volume of the tank ( 0.04 volume to area ratio). Under these conditions, the best results of $\mathrm{CO}_{2}$ emission are obtained, the solar portion is $83 \%$ and the price of reducing the carbon footprint is $\$ 0.75 / \mathrm{kg}$.

Sarabia et al. [44] proposed a new design which connected the solar collector is directly with the single effect absorption cycle. The temperature of generation influenced by the size of device and of the solar collector surface. The $\mathrm{LiBr} / \mathrm{H}_{2} \mathrm{O}$ absorption cycle was simulated under the Spanish weather conditions.

Shekarchiana et al. [47] based their study on weather conditions in Iran, spanning over a full year. The study focused on the power requirements per unit area, and overall cost of energy. The relationship between the cost reduction and absorption coolers performance was also analyzed. The results showed that the energy used per unit area was higher when using absorption coolers, but the cost is lower, there is a direct relationship between the absorption cooler performance and costs, while an increase in the cooler performance about is 0.1 , produces a $\$ 50 / \mathrm{m}^{2}$ cost reduction.

Tsoutsos et al. [49] proposed a simulation of a complete cooling system. The simulation included are a water cooling tower, a $70 \mathrm{~kW} \mathrm{LiBr} / \mathrm{H}_{2} \mathrm{O}$ absorption cooler, a $50 \mathrm{~kW}$ supplementary compression cooler, a storage tank, a secondary heat source, a supplementary $87 \mathrm{~kW}$ preheater and a $500 \mathrm{~m}^{2}$ solar collector. The payback period of the initial cost ( $\$ 173.992$, without funding subsidies) is of 11.5 years, but it can be reduced to 6.9 years in case of $40 \%$ funding, which brings the initial investment to $\$ 104.395$. Gmri [20] studied the cooling water by using three types of absorption cycles such as single effect, double effect and triple effect, and applying the same output level $300 \mathrm{~kW}$ on all three systems. The simulations followed the results on the exergetic efficiency, the performance coefficient and the ratio of mass flow rate of the generated refrigerant. For the three systems proposed, the study reached several conclusions. The first conclusion showed that higher generator and evaporator temperatures achieve higher COP of the cycle, whereas higher condenser temperature achieves lower COP. The second conclusion indicated that the best COP and exergetic efficiency can be obtained by reaching an optimum generator temperature, which can be identified for each condenser and evaporator temperature. The results showed that for the condensing temperatures $\left(33-39{ }^{\circ} \mathrm{C}\right)$, and evaporating temperatures $\left(4-10^{\circ} \mathrm{C}\right)$, the maximum COP obtained is between $(0.73-0.79)$ for the single effect system, and (1.22-1.42) for the double effect system, and (1.62-1.90) for the triple effect system. In terms of exergetic efficiency, the values obtained are between $12.5-23.2 \%$ for the single effect system, and $14.3-$ $25.1 \%$ for the double effect system, and between $17.7-25.2 \%$ for the triple effect system. The results showed that the COP obtained for the double effect solution was twice as high as the results for the single effect solution, while the results of exergetic efficiency are slightly better for the double effect system than the single effect system. Fong et al. [19] a comparative study of five different cooling systems. The systems were analyzed included various solutions: such as solar absorption refrigeration, solar electric compression refrigeration, solar solid desiccant cooling, solar mechanical compression refrigeration and solar adsorption refrigeration. The simulations were performed under the weather conditions in Hong Kong (subtropical climate), the most suitable solutions to be implemented are "solar absorption refrigeration and solar electric compression refrigeration with flat plate and evacuate tubes collectors".

Koroneos et al. [29] conducted a financial analysis on the implementation of a $70 \mathrm{~kW} \mathrm{LiBr} / \mathrm{H}_{2} \mathrm{O}$ solar absorption cooler. The results of this study indicated was a 24 -year payback period implementation, which costs approximately $€ 138,000$, and the cost of a traditional cooling system was $(€ 107,640)$.

Desideri et al. [14] they studied of two different applications of solar absorption systems. They selected two different fields in order to assess the implementation of the systems (industrial refrigeration and commercial air conditioning). The industrial refrigeration solution focused on a replacement or additional solution for a meat manufacturing company for their refrigeration necessities. For this application, the solar flat plate collector was used 
coupled with an absorption chiller. The commercial air conditioning solution was applied on a hotel sit in Italy. For this application, the proposed took into consideration higher operational flexibility for the heating and cooling requirements. The technical and economic analyses were combined with the experimental analysis in order to assess the benefits and drawbacks and to identify the most suitable solution for each application.

Kim and Infante Ferreira [28] performed simulations on different absorption cycles for solar cooling. In terms of initial investment, they found that a half-effect $\left(\mathrm{LiBr} / \mathrm{H}_{2} \mathrm{O}\right)$ cycle is the most suitable solution for solarpowered cooling systems. This is based on the characteristics of the working liquid (superior thermodynamic properties) and on the fact that the half-effect absorption cycle needs a low operating temperature. The study included a simulation of the proposed system in an extremely hot environment, and the temperature can be reduced in both operating modes (direct and indirect cooling). The temperature of the water chilled by the cooler was reduced from $90{ }^{\circ} \mathrm{C}$ at a $35^{\circ} \mathrm{C}$ environment temperature to $5.7{ }^{\circ} \mathrm{C}$ and $7.8{ }^{\circ} \mathrm{C}$, for each operating mode. The COP recorded was 0.38 and 0.36 , for direct and indirect cooling modes, respectively. When the ambient temperature reached $50^{\circ} \mathrm{C}$, the direct air cooling solution COP was decreased to $81.6 \%$ and $37.5 \%$, as compared with the functioning at $35{ }^{\circ} \mathrm{C}$. For the indirect cooling system, the COP reached $75 \%$ and $35.6 \%$.

Balghouthi et al. [11] applied simulation of Tunisian weather conditions and using TRNSYS and EES applications, and assessed the possible implementation opportunities of solar-powered absorption cooling. The data available for the simulation covered one-year weather conditions for Tunis. The proposed system for building of (150 $\mathrm{m}^{2}$ ), for which the best results were obtained, included the following components: $11 \mathrm{~kW} \mathrm{LiBr} / \mathrm{H}_{2} \mathrm{O}$ absorption cooler, $\left(30 \mathrm{~m}^{2}\right)$ flat-plate solar collector area, $35^{\circ}$ tilt angle and $\left(0.8 \mathrm{~m}^{3}\right)$ hot water storage tank.

The simulation proposed by Thomas and Philppe [48] included all the necessary components needed to assess the power usage of an air conditioning system. The elements simulated included the absorption cooler, the solar panels area, a heater, storage components, rejection system, pumps, heating-cooling networks, emission circuit. The simulation was able to improve in some cases the energy consumption. A $34.9 \%$ energy saving was obtained by employing three different control strategies (compared to traditional air conditioning solutions). In the work of Saygh [45] a theoretical analysis of the thermal parameters was conducted. The study used a solar-powered cooling system, with flat plate solar collectors, a thermal storage tank and supplementary heater. A program was developed with the purpose of evaluating the performance of the properties of the absorption cycle. The following parameters were included in the study: COP and solar useful heat gain. The conditions applied in Aleppo, with evaporating temperatures between $5^{\circ} \mathrm{C}$ and $15^{\circ} \mathrm{C}$ and generator temperatures between $80^{\circ} \mathrm{C}$ and $100^{\circ} \mathrm{C}$. The results of the simulation were confirmed by actual conditions and the study confirmed the feasibility of such an installation in Aleppo.

Casils [13] provided a detailed analysis of a comparison between the solar cooling and heating systems installed in Spain and other solar cooling systems. The study was conducted using TRNSYS dynamic simulations. Izquierdo et al. [24] simulation a solar-powered absorption system $\mathrm{H}_{2} \mathrm{O} / \mathrm{LiBr}$ with evaporating temperature $5{ }^{\circ} \mathrm{C}$, using flat-plate solar collectors. The system analyzed is a double stage air/water system, that reached better results in terms of condensation temperatures, than single-stage cycles $\left(13{ }^{\circ} \mathrm{C}\right.$ higher condensation temperatures). Crystallization is significantly reduced in the double-stage cycle, until $53{ }^{\circ} \mathrm{C}$. The COP obtained by the double-stage cycle is 0.38 and it required $80^{\circ} \mathrm{C}$ generator temperatures, while the condensation temperatures reached $50{ }^{\circ} \mathrm{C}$.

Assilzadeh et al. [8] proposed a system suitable for tropical regions, similar to Malaysian weather conditions. The cooler model was based on Arkla WF-36 (single-phase, $\mathrm{H}_{2} \mathrm{O} / \mathrm{LiBr}$ absorption air cooler). The TRNSYS simulation included the high demand of cooling during daytime, according to weather conditions. The results indicated that reach the requirements the $3.5 \mathrm{~kW}$ system, needs a $\left(0.8 \mathrm{~m}^{3}\right)$ hot water storage, $\left(35 \mathrm{~m}^{2}\right)$ evacuated tubes and a solar collector at $\left(20^{\circ}\right)$ slope.

Joudi and Abdul-Ghafour [27] proposed a full simulation of a $\mathrm{H}_{2} \mathrm{O} / \mathrm{LiBr}$ absorption cooling system using an integrated preprogram. Based on the results of the simulation, the authors proposed a general design procedure for solar cooling systems. The procedure was presented on a graphical form, named the cooling f-chart, and it is intended to reduce the designer's efforts in forecasting the energy requirements of a solar-powered absorption water cooling system. 
Atmaca and Yigit [9] were simulated a 105-kW constant cooling load, for the solar cooling system in the weather conditions in Antalya, Turkey. The authors developed a module for a computer program that is able to replicate different configurations of the cycle. The results showed that the cooling system needs a $50 \mathrm{~m}^{2}$ solar collector surface and a $3750 \mathrm{~kg}$ storage tank.

\section{Experimental Investigations}

Rosick and Batlles [41] analyzed of a solar-assisted air conditioning system, with two cooled water tanks for storage. The components of the system are $160 \mathrm{~m}^{2}$ surface solar collectors, absorption cooler (hot water driven), supplementary heater, two cooled water storage tanks, two hot water storage tanks and a cooling tower. The savings obtained by applying the proposed operation flow were 1.7 tons of $\mathrm{CO}_{2}$ and $30 \%$ of water during the summer, but the deionized water consumption was also reduced, together with the outside operation noise. The absorption cooler was able to work during periods when there was no demand, which reduces the on/off cycles. The main drawback is the system size and storage limitations.

Lizaret et al. [30] tested a new adiabatic flat fan sheets absorber in a single effect $\mathrm{H}_{2} \mathrm{O} / \mathrm{LiBr}$ absorption cooler. Palacios also tested the use of the flat fan sheet configuration and concluded that it has higher mass transfer coefficient than absorbers of other types (spray or falling film). The cooling system included a $1.5 \mathrm{~m}^{3}$ hot water storage tank and a $1 \mathrm{~m}^{3}$ absorption unit. The experiment was carried out on a 10-day period, under the weather conditions in Madrid, during summer, for a $40 \mathrm{~m}^{2}$ surface. The average collector efficiency was 0.27 , the COP was 0.53 and the solar COP was 0.062 .

Bujedo et al. [12] also applied their analysis under Spanish weather conditions, for office space. The parameters of the experiment were the following: $200 \mathrm{~m}^{2}$ office area, $77.5 \mathrm{~m}^{2}$ collector area, $35 \mathrm{~kW}$ cooler, one $(1$ $\mathrm{m}^{3}$ ) cold water storage tank, and two $\left(2 \mathrm{~m}^{3}\right)$ hot water storage tanks. The experiment aimed to apply various control procedures: full load operation with on/off controller (traditional approach); use the on/off controller to adjust the condenser temperatures to the generator temperature and the load; manage the heat source liquid flow rate through the generator in order to adjust the condensing temperature and the load. The results showed an improved solar field yield (between 7 and 12\%) and a higher overall system efficiency (between 44 and 48\%). The conclusions indicated that the two new proposed control strategies show better results than the traditional strategy.

Al-Dadah et al. [7] used for their experiments propane as refrigerant. The gas was mixed with different "lubrication oils - naphthenic mineral oils 32 and 64 and alkylated benzene oils AB150 and AB300". The best mixture resulted from the combination propane - alkylated benzene AB300. This mixture was used in a single stage absorption cycle $\left(1.3 \mathrm{~kW}^{\circ} \mathrm{C}\right)$. The system contains heat pipes that recover the absorption heat, reducing the heat required from the generator. These pipes are installed between the absorber and the pre-generator. The COP of the system reached 1. The location for the system proposed by Qu et al. [40] was Carnegie Mellon University, in Pittsburgh. The system was a $16 \mathrm{~kW}$ double-effect absorption cooling system, powered by solar energy. The design included a $52 \mathrm{~m}^{2}$ parabolic trough solar collectors, a heat exchanger with pumps and control valves, cooling tower integrated with the $\mathrm{LiBr} / \mathrm{H}_{2} \mathrm{O}$ absorption chiller and a natural gas auxiliary heater. The system functioned successfully for more than one year and during the summer months, the system recorded a $33-40 \%$ efficiency at a $150-160{ }^{\circ} \mathrm{C}$ heat transfer fluid temperatures. The absorption cooler COP was between 1.0 and 1.1 and the solar COP was between $0.33-0.44$. The output capacity was of maximum $12 \mathrm{~kW}$, which is below the $16 \mathrm{~kW}$ capacity, as a result of the highly humid weather conditions, with relatively low solar radiations $\left(600-850 \mathrm{~W} / \mathrm{m}^{2}\right)$.

Ortiz et al. [36] and Mamoli et al. [32] focused on high-desert weather conditions and based their experiment on a $7000 \mathrm{~m}^{2}$ educational building. The solar cooling system analyzed was a Yazaki single-effect $\mathrm{LiBr} / \mathrm{H}_{2} \mathrm{O}$ water chiller and had two types of solar collectors: flat plate collectors $\left(124 \mathrm{~m}^{2}\right)$ and vacuum tubular collectors $\left(108 \mathrm{~m}^{2}\right)$. The cooling liquid was water-glycol mixture that went through the collectors and the heat exchanger linked to the $34 \mathrm{~m}^{3}$ hot water storage tank with thermal stratification. The hot water temperature range was between 70 and $95{ }^{\circ} \mathrm{C}$. Seven tanks with volume $\left(50 \mathrm{~m}^{3}\right)$ for cold water storage tanks with thermal stratification were used to store the cold water. The system was assisted by the cold water and steam systems of the campus in case of insufficient heating or cooling production. The overall results indicated that the proposed system can produce 
$18 \%$ of the required cooling load, with the possibility to increase this percentage to up to $36 \%$ by adjustments to the air handler operation and better insulation of the storage tanks.

The experiment proposed by Rosiek and Batles [42] focused on the "Solar Energy Research Center of Spain". The location has a solar-powered single-effect absorption cooling system installed, which is responsible for providing heating and cooling, depending on season. The necessary power for providing the required heating is of $8124 \mathrm{kWh}$ and for cooling, is of $13255 \mathrm{kWh}$ per year. The solar collectors were flat-plate and the total surface of collectors was $160 \mathrm{~m}^{2}$. For cooling, a 70-kW single effect absorption chiller was used. The data collected in a control and data-acquisition system covered a full year of operation. The researchers concluded that the solar collectors are sufficient for providing the necessary power for cooling during the summer months and heating during the winter months. The average COP calculated for the summer period was 0.6 and the average cooling capacity was $40 \mathrm{~kW}$.

Hidalgo et al. [23] analyzed a single effect $\mathrm{LiBr}-\mathrm{H}_{2} \mathrm{O}$ system at Spanish summer weather conditions for cooling a $90 \mathrm{~m}^{2}$ area. The flat plate solar collectors spread on a $50 \mathrm{~m}^{2}$ area and was able to produce $6-10 \mathrm{~kW}$ cooling. The results were compared to a vapor compression cycle work with R407C system with a $2.4 \mathrm{COP}$ and focused on economic savings, environmental impact and system performance. The results showed that the energy costs were $62 \%$ and the $\mathrm{CO}_{2}$ emission were also $36 \%$ lower with the solar powered system, which used $56 \%$ solar power and $44 \%$ natural gas.

The experimental facility built by Rodrigues Hidalgo et al. [23] was a $35-\mathrm{kW}$ single-effect $\mathrm{LiBr}-\mathrm{H}_{2} \mathrm{O}$ absorption system with $50 \mathrm{~m}^{2}$ flat-plate solar collectors. The measurements were performed during the summer of 2004 and the system worked at partial load. As a result, the value of seasonal COP was 0.33 , which led to the conclusion that a more suitable size of the absorption system and nominal functioning conditions could increase the COP in order to increase the solar fraction.

Jelinek et al. [26] analyzed a triple pressure level single stage absorption cycle. For the experiment, the researchers used various refrigerant-absorbent combinations. The design included a special jet ejector placed at the absorber inlet with the role of recovering the pressure and improving the absorbent-refrigerant mix Fig.5. The absorbent (dimethylethylenurea (DMEU)) was mixed with various refrigerants: "hydrofluorocarbon (HFC) (R32, R125, R134a and R152a) and hydrochlorofluorocarbon (HCFC) (R22 and R124) ". Based on the impact on the COP and on the circulation ratio of the generator, evaporator, and condenser temperatures, the authors concluded that the best combinations were R124-DMEU (from the HCFCs) and R125-DMEU (from the HFCs). The R125-DMEU experiment was conducted again in order to increase the $\mathrm{COP}$ and to reduce the generator temperature requirements.

Fong et al. [19] measured the performance of an integrated system consisting of a solar powered $\mathrm{H}_{2} \mathrm{O} / \mathrm{LiBr}$ absorption chiller and a free cooling system. The location of the system was in Oberhausen, Germany. The system is functioning since August 2002 for cooling a $270 \mathrm{~m}^{2}$ area. The system includes the following components: "10-TR absorption chiller, $108 \mathrm{~m}^{2}$ vacuum tube collectors, $134 \mathrm{~kW}$ cooling tower, $6.8 \mathrm{~m}^{3}$ hot water storage tank and $1.5 \mathrm{~m}^{3}$ cold water storage tank". The following conclusions were drawn:

- The free cooling rate during certain months is up $70 \%$; additionally, the system is able to provide $25 \%$ of the total cooling necessity over a 5-year operation time. The eco-efficient system needs to be developed to the overall design of the system. This will significantly reduce the need for those devices with multiple design purposes, such as a cooling tower.

- The average monthly solar heat fraction ranges from $31.1 \%$ to $100 \%$; overall, during the 5-year operation time, the average is approximately between $34.1 \%$ and $60 \%$.

- The collectors area efficiency was on average $41.8 \%$, with a $28.3 \%$ for the overall 5 -year operation time .

- During sunny days, with no clouds and solar radiation, the efficiency of the solar collectors is between 0.352 and 0.492 , the solar heat fraction is between 0.33 and 0.41 , while the COP ranges between 0.37 and 0.81 .

- The collector area is $4.23\left(\mathrm{~m}^{2} / \mathrm{kW}\right.$ cold) in order to collect the most solar energy and power the absorption cooler.

- The solar powered cooling system provided $8125 \mathrm{kWh}$ to support the cooling system between August 2002 and November 2007. 
Syed et al. [46] used for their experiment a $35 \mathrm{~kW} \mathrm{LiBr} / \mathrm{H}_{2} \mathrm{O}$ absorption system, with flat-plate collectors $\left(49.9 \mathrm{~m}^{2}\right.$ surface), a $2 \mathrm{~m}^{3}$ stratified hot water storage tank with temperatures $\left(65-90{ }^{\circ} \mathrm{C}\right)$. The maximum capacity measured was between 0.42 and 0.34 and the efficiency of the collector was $50 \%$ (daily average). This system is most suitable for dry and hot weather conditions, with high differences in relative humidity and dry bulb temperature. Li and Sumathy [31] presented a new partitioned hot water storage tank design. The comparison of the system was done with another traditional design hot water tank, which was not partitioned. The parameters of the system were: $\mathrm{LiBr} / \mathrm{H}_{2} \mathrm{O}$ solar powered absorption cooling with $38 \mathrm{~m}^{2}$ flat-plate collectors area and with $4.7 \mathrm{~kW}$ cooling capacity. The new tank is divided into two parts, with the upper part representing approximately one quarter of the entire volume. The solar cooling is effective 2 hours earlier in the new system, compared to the traditional system. The COT of the new system was also $15 \%$ higher than that of the traditional system (0.07). Another benefit of the new proposal is the possibility to operate it during rainy days, as opposed to the comparison system, which cannot provide cooling.

\section{Solar-Powered Absorption Cooling Recent Designs}

Bellos et al. [55] A solar cooling system of $100 \mathrm{~kW}$ was designed under the climatic conditions of Athens in Greece. The system contained an evacuated tube collector, storage tank and single stage absorption chiller with $\mathrm{LiBr}$ $\mathrm{H}_{2} \mathrm{O}$. Various sets of solar panel areas were selected from $150 \mathrm{~m}^{2}$ to $600 \mathrm{~m}^{2}$, and also different sets of storage tank were tested from $6 \mathrm{~m}^{3}$ to $16 \mathrm{~m}^{3}$. The best cases were assessed financially, the results showed that $450 \mathrm{~m}^{2}$ of evacuated tube collectors with $14 \mathrm{~m}^{3}$ storage tank is the ideal solution with a financial recovery period of 15 years.

Said et al. [43] proposed new designs of solar powered absorption systems for $24 \mathrm{~h}$ operation. The authors proposed two designs, one with continuous operation and one with intermittent operation. The continuous operations system includes storage for cold water, refrigerant and heat, while the intermittent operation system includes a cold water storage tank. These are required in order to provide continuous cooling (during the day and night). The highest COP was recorded for the heat storage system, but it requires proper insulation. For the weather conditions in Dhahran, Saudi Arabia, the most suitable solution was considered the system with refrigerant storage for continuous operation. The majority of cooling system use water cooling towers, which however have issues related to water consumption, generating higher costs, which are examined closely.

Mark et al. [33] demonstrated the difficulties in defining the appropriate refrigerating capacity. It is possible to achieve thermal comfort inside a building by installing an oversized chiller working below nominal conditions, while an undersized chiller working in nominal conditions cannot provide thermal comfort.

A $4.5 \mathrm{~kW} \mathrm{LiBr} / \mathrm{H}_{2} \mathrm{O}$ solar thermal absorption cooling system with a cold storage was proposed in the study of Agyenim et al. [1]. The system was installed and tested in Cardiff, UK. The vacuum tube collectors had a $12 \mathrm{~m}^{2}$ area, with an ethylene glycol-based collector liquid. The minimum temperature for chiller activation was $80{ }^{\circ} \mathrm{C}$. The temperature of the cold water produced was between $7-16^{\circ} \mathrm{C}$. The mean daily thermal COP was 0.58 and the mean daily electrical COP was 3.6. For the cold season, the recommendation of the authors was to integrate the solar powered cooling system with the heating and hot water systems. The chiller continued to consume energy even when not cooling, which makes it the highest power consumer.

A solar-biomass hybrid absorption cooling system was proposed by Prasartkaew and Kumar [39]. This type of system (intended for residential installation) has the following components: single effect absorption chiller, hot water boiler using biomass gas and water heater using solar power with a storage tank, with the hot water boiler installed between the storage tank and the absorption chiller. The insulated boiler functions as supplementary boiler, during insufficient solar power or as the main source of heat, during unavailable solar power. The chiller COP recorded was 0.7 and of the entire system was 0.55 , with a charcoal consumption of $24.44 \mathrm{~kg}$ /day for a continuous 24 $\mathrm{h}$ operation. The system was installed in Bangkok. The proposed system had several benefits in terms of greenhouse gas emissions reduction and increased comfort.

Helm et al. [22] proposed a solar powered absorption cooling system that included a low temperature latent heat storage and a dry air cooler. The performance of the system was compared to a conventional system with a cooling tower. The heat ejected from the absorption chiller is stored and released in the ambient during low temperature periods. In an application without cooling tower, it is easier to implement the absorption technology, 
especially for installations of lower capacity. Storing the latent heat reduces the size of the system, as opposed to the solar collectors in conventional designs with wet cooling towers. The difference comes from cooling dry air. For the experiment, the researchers used calcium chloride hex hydrate with phase transition at temperatures between $27{ }^{\circ} \mathrm{C}$ and $29^{\circ} \mathrm{C}$. It is a phase-change material (PCM), transitioning from between melting and solidification. As a result, an improved volumetric storage was obtained, which was estimated as being ten times higher than in the case of water heat storage. The latent heat storage also enables the switching to the supplementary power source during low demand and peak hours with a very small power consumption increase. The latent heat storage is installed within the chiller rejection loop. The cost reduction for operating the system was obtained as an effect of the lower night cost of electricity. The constant load and less peaks during the day also had a positive impact on cost reduction and overall system efficiency.

The $\mathrm{LiBr} / \mathrm{H}_{2} \mathrm{O}$ single-effect absorption cooling system proposed by Pongtornkulpanich et al. [37] is a $10 \mathrm{TR}$ solar powered system with evacuated tube solar collector of $72 \mathrm{~m}^{2}$. The results indicated that the solar power produced $81 \%$ of the required power for the cooling system and an LPG-fired auxiliary heating unit supplemented the remaining 19\% necessary. Mazloumi et al. [34] proposed a solar powered single-effect absorption cooling system for supplying a cooling load peak of $17.5 \mathrm{~kW}$. The application was intended to provide the cooling requirements for a typical house in Ahwaz. For the design, the authors proposed a horizontal N-S parabolic trough collector with an insulated heat storage tank. The necessary cooling load can be provided with a minimum $57.6 \mathrm{~m}^{2}$ collector area. For spaces that require large cooling load amounts, the flat-plate or evacuated tubular solar collectors need an extensive installation surface, which often turns impractical. The parabolic trough collectors are more efficient in terms of solar thermal energy collection in areas with convenient display. The cooling system is able to start earlier operation and to even continue to operate in the absence of direct sunlight, as opposed to stationary collectors, which depend on direct sunlight.

Ahmed Hamza et al. [2] collected the results of a solar powered single-effect $\mathrm{LiBr} / \mathrm{H}_{2} \mathrm{O}$ absorption chiller installed in Oberhausen, Germany, operated since August 2002. The solar powered system provided the cooling requirements of a $270 \mathrm{~m}^{2}$ space and it was integrated with a free cooling system. The components of the analyzed design were: $35.17 \mathrm{~kW}$ cooling absorption chiller, $134 \mathrm{~kW}$ cooling tower, $108 \mathrm{~m}^{2}$ vacuum tube collector, $1.5 \mathrm{~m}^{3}$ cold water storage tank and $6.8 \mathrm{~m}^{3}$ hot water storage tank. For a 5 -year operation period, free cooling provided up to $70 \%$ of the cooling requirements, with a $25 \%$ average. The COP of the collectors was between 0.352 and 0.492 and the COP of the chiller was between 0.37 and 0.81 during sunny days.

Ali Rezaie et al. [51] experimental study was conducted to the efficiency of thermal conductivity to nanoparticles of iron oxide and magnesium in the ethylene experimental results showed: The efficiency of thermal conductivity of nanotubes iron and magnesium in the ethylene is high compared to other nanoparticles and also in terms of cost reduction are appropriate.

Hemmat Esfe et al. [53] experimental study was conducted to demonstrate the presence, size and concentration of nanoparticles on thermal conductivity, dynamic viscosity, and heat transfer properties. Experimental results showed: The presence of nanoparticles in the fluid and the high number of Reynolds leads to an increase in the number of Nusselt in the turbulent flow. When the number of Reynolds is about 22,000, the number of Nusselt increases by $11.8 \%$ in the volume of $1 \%$ This value is $10.35 \%$ when the number of Reynolds about 5100 at the size of $1 \%$.

Hemmat Essaf et al. [54] an experimental study of the effect of temperature and volume on thermal conductivity of $\mathrm{Al}_{2} \mathrm{O}_{3}$, Nts. Hydrogen nanoparticles experimental Results showed: The thermal conductivity of $\left(\mathrm{Al}_{2} \mathrm{O}_{3}\right.$, Nts). Increasing as the temperature increases.

Hemmat et al. [52] investigate how $\mathrm{MgO}$ can benefit from nanoparticles in reducing cost and increasing heat transfer coefficient. The results showed that the cost reduction is about $38 \%$ and the heat transfer coefficient is increased.

\section{CONCLUSIONS}

The indoor air quality can be improved with the use of solar powered cooling systems, which are available in both stand-alone installations, and integrated with conventional air conditioning solutions. These types of solar 
powered systems are available for all types of buildings, being able to provide cooling or heating and hot water, depending on the season and necessities. In terms of economic efficiency, two of the components have the most impact, these being the solar power collection and the refrigeration technologies.

Another factor with significant impact is the availability of the solar power, based on the location of the installation. The majority of solar powered cooling systems use $\mathrm{LiBr} / \mathrm{H}_{2} \mathrm{O}$ as working liquids and single-effect absorption chillers. The double-effect chillers are more efficient than the single-effect ones, with higher COP results. This has been made possible through the evolution of gas-fired systems, which reduce the solar heat requirement for each $\mathrm{kW}$ of cooling. The drawback of these types of systems is the cost of the high temperature solar collectors necessary in these installations, which is currently still high.

The solar-powered double effect absorption cooling systems are nevertheless viable solutions for high cooling load requirements for buildings with reduced installation space. However, they require high levels of direct sun irradiation. The COP reported so far for half-effect absorption and two-stage absorption chillers is still quite low (0.3 and 0.4). Although these types of chillers can be used with flat-plate or evacuated tubular solar collectors, their efficiency is acceptable only when operated in air-cooling mode. They are more suitable for implementations in hot and dry regions, which suffer from water shortage.

Half-effect absorption and two-stage absorption chillers are more efficient and $50{ }^{\circ} \mathrm{C}$ condensing temperatures, with no crystallization risk. The following suggestions are built on the research activity on solarpowered single-effect absorption cooling systems. The main choice of solar collectors for absorption cooling systems are currently the flat-plate and evacuated tubular solar collectors, and they are likely to maintain their leading market position in the near future. Competitive alternatives can be provided by integrated solar cooling and power generation plants based on CPVT technology and single-effect absorption chillers. With further improvements of the CPVT technology, the economic and technological advantages of such systems can be developed, becoming more attractive for efficient installations. The heat storage water tanks used in solar powered cooling systems have volumes ranging between 0.01 and $0.08 \mathrm{~m}^{3} / \mathrm{m}^{2}$, and the average regeneration temperature for driving the solar absorption cycle is $88.5^{\circ} \mathrm{C}$. Various system configurations have been proposed to raise the solar fraction in order to increase the operation time to periods with no sun light (night). Another proposal is that Nano fluid can be used in the solar cooling system as an alternative to classical fluid, which can increase the performance of solar refrigeration units and increase their efficiency. This proposal could be introduced in future research work linking solar cooling units with Nano fluid. Thermal insulation can also expand the functioning time of absorption systems. The main direction observed is the necessity to develop solar air conditioning systems in order to contribute to the energy saving movement. A solar powered air conditioning system can help save 40 to $50 \%$ energy and reduce the fossil fuel consumption, compared to conventional air conditioning systems.

\section{REFERENCES}

[1] Agyenim F., Knight I.,and Rhodes M. Design and experimental testing of the performance of an outdoor $\mathrm{LiBr} / \mathrm{H}_{2} \mathrm{O}$ solar thermal absorption cooling system with a cold store. Solar Energy 2010, Vol.84: 735-744. doi:/10.1016/.2010.01.013.

[2] Ahmed Hamza H., Peter Noeres, and Clemens Pollerberg. Performance assessment of an integrated free cooling and solar powered single-effect lithium bromide-water absorption chiller. Solar Energy, 2008; 82: 1021 -1030. doi: /10.1016/.2008.04.011.

[3] AL-UGLA A., M.A.I. El-Shaarawi, S.A.M. Said, and A.M. Al-Qutub. Techno-economic analysis of solarassisted air-conditioning systems for commercial buildings in Saudi Arabia. Renewable and Sustainable Energy Reviews, 2016; 54: 1301 -1310. doi: /10.1016/.2015.10.047.

[4] Allouhi A., Kousksou T., Jamil A., El Rhafiki T., Mourad Y., and Zeraouli Y. Economic and environmental assessment of solar air-conditioning systems in Morocco. Renewable and Sustainable Energy Reviews, 2015;50: 770 - 781. doi: /10.1016/.2015.05.044.

[5] Al-Alili A., Hwang Y., and Radermacher R. Review of solar thermal air conditioning technologies. International Journal of Refrigeration, 2014; 39: 4 - 22. doi: /10.1016/.2013.11.028. 
[6] Al-Alili, A., Islam, M.D., Kubo, I., Hwang, Y., and Radermacher, R. Modeling of a solar powered absorption cycle for Abu Dhabi. Appl. Energy, 2012; 93: 160-167. doi:10.1016/.2010.11.034.

[7] Al-Dadah, R.K., Jackson, G., and Rezk, A. "Solar powered vapor absorption system using propane and alkylated benzene AB300 oil". Appl. Therm. Eng. 2011; 31: 1936-1942. doi /10.1016/. 2011.02.040.

[8] Assilzadeh F., Kalogirou S.A., Ali Y., and Sopian K. Simulation and optimization of a LiBr solar absorption cooling system with evacuated tube collectors. Renew Energy, 2005; 30 (8):114359.doi:/10.1016/.2011.02.040.

[9] Atmaca I, and Yigit A. Simulation of solar-powered absorption cooling system. Renew Energy 2003;28(8):1277-93. doi: /10.1016/S0960-1481(02)00252-5.

[10] Baniyounes, Ali M., M. G. Rasul, and Mohammad Masud K. Assessment of solar assisted air conditioning inCentral Queensland's subtropical climate, Australia. Renewable energy 2013; 50: 334 - 341. doi:/10.1016/.2012.06.042.

[11] Balghouthi M., Chahbani M. H., and Guizani A. Feasibility of solar absorption air conditioning in Tunisia. Build Environ, 2008; 43(9):1459-70. doi:/10.1016/.2007.08.003.

[12] Bujedo, L.A., Rodri'guez, J., Martı'nez, P.J., Experimental results of different control strategies in a solar air conditioning system at part load. Solar Energy, 2011; 85: 1302-1315 doi.:/10.1016/.2011.03.009.

[13] Casals, Xavier Garcia. Solar absorption cooling in Spain: perspectives and outcomes from the simulation of recent installations. Renewable energy, 2006; 31(9): 1371 - 1389. doi:/10.1016/.2005.07.002.

[14] Desideri, Umberto, Stefania Proietti, and Paolo Sdringola. Solar-powered cooling systems: Technical and economic analysis on industrial refrigeration and air-conditioning applications. Applied Energy, 2009;86(9): 1376 -1386. doi:/10.1016/.2009.01.011.

[15] Evangelos Bellos., \& Christos Tzivanidis. Energetic and financial analysis of solar cooling systems with single effect absorption chiller in various climates. Applied Thermal Engineering, 126, 809-821. doi:/10.1016/.2011.10.025.

[16] Eicker, U., Pietruschka, D., Pesch, R., Heat rejection and primary energy efficiency of solar driven absorption cooling systems. Int. J. of Refrigeration, 2012; 35: 729-738. doi:/10.1016/.2012.01.012

[17] Fasfous, A., J. Asfar, A. Al-Salaymeh, A. Sakhrieh, Z. Al_hamamre, A. Al-bawwab, and M. Hamdan. Potential of utilizing solar cooling in The University of Jordan. Energy conversion and management, 2013; 65: 729-735. doi:10.1016/.2012.01.045.

[18] Farshi L. G., Mahmoudi S.M., Rosen M. A., Yari M., and Amidpour M. Exergoeconomic analysis of double effect absorption refrigeration systems". Energy Convers Management, 2013; 65:13-25. doi:/10.1016/.2012.07.019.

[19] Fong, K. F., T.T. Chow, C.K. Lee, Z. Lin, and L.S. Chan. Comparative study of different solar cooling systems for buildings in subtropical city. Solar Energy, 2010; 84(2): 227- 244. doi:/10.1016/.2009.11.002.

[20] Gomri and Rabah. Investigation of the potential of application of single effect and multiple effect absorption cooling systems. Energy Conversion and Management, 2010; 51(8): 1629 - 1636. doi:/10.1016/.2009.12.039.

[21] Hang, Yin, Ming Qu, and Fu Zhao. Economical and environmental assessment of an optimized solar cooling system for a medium-sized benchmark office building in Los Angeles, California. Renewable Energy, 2011; 36(2): 648- 658. doi:/10.1016/.2010.08.005.

[22] Helm M, Keil C, Hiebler S, Mehling H, and Schweigler C. Solar heating and cooling system with absorption chiller and low temperature latent heat storage: energetic performance and operational experience. Int. J. of Refrigeration 2009; 32(4):596-606. doi:/10.1016/.2009.02.010.

[23] Hidalgo, M.C.R., Aumente, P.R., Milla' n, M.I., Neumann, A.L., and Mangual, R.S., Energy and carbon emission savings in Spanish housing air-conditioning using solar driven absorption system. Appl. Therm. Eng, 2008; 28: 1734-1744. doi:/10.1016/.2007.11.013.

[24] Izquierdo M, Venegas M, Rodriguez $\mathrm{P}$, and Lecuona A. Crystallization as a limit to develop solar air-cooled $\mathrm{LiBr}-\mathrm{H}_{2} \mathrm{O}$ absorption systems using low-grade heat. Sol. Energy Mater Sol. C., 2004; 81:205-216.

[25] Jelinek, M., Levy, A., and Borde, I. Performance of a triple pressure level absorption/compression cycle. 
Applied Thermal Engineering, 2012; 42: 2-5. doi:/10.1016/.2003.11.002.

[26] Jelinek, M., Levy, A., and Borde, I. The performance of a triple pressure level absorption cycle (TPLAC) with working fluids based on the absorbent DMEU and the refrigerants R22, R32, R124, R125, R134a and R152a. Applied Thermal Engineering,2008; 28:1551-1555. doi:/10.1016/.2008.01.023.

[27] Joudi K. A. and Abdul-Ghafour Q.J. Development of design charts for solar cooling systems. Part I: Computer simulation for a solar cooling system and development of solar cooling design charts. Energy Convers Manage, 2003; 44(2): 313-39. doi:/10.1016/S0196-8904(02)00045-6.

[28] Kim D.S. and Infante Ferreira C. A. Air cooled $\mathrm{LiBr}$-water absorption chillers forsolar air conditioning in extremely hot weathers. Energy Convers Manage, 2009; 50(4):1018-25. doi:/10.1016/.2008.12.021.

[29] Koroneos C, Nanaki E, and Xydis G. Solar air conditioning systems and their applicability - an exergyapproach. Resour Conserv Recycl, 2010; 55:74-82. doi:/10.1016/.2010.07.005.

[30] Lizarte, R., Izquierdo, M., Marcos, J.D., and Palacios, E. An innovative solar-driven directly air-cooled $\mathrm{LiBreH}_{2} \mathrm{O}$ absorption chiller prototype for residential use. Energy Build, 2012; 47: 1-11. doi:/10.1016/.2011.11.011.

[31] Li Z. F., and Sumathy K. Experimental studies on a solar powered air conditioning system with partitioned hot water storage tank. Solar Energy, 2001; 71(5) : 285-297. doi:/10.1016/S0038-092X(01)00064-0.

[32] Mammoli A, Vorobieff P, Barsun H, Burnett R, and Fisher D. Energetic economic and environmental performance of a solar-thermal-assisted HVAC system. Energy Build, 2010; 42(9):524-1535. doi:/10.1016/.2010.03.023.

[33] Marc O, Lucas F, Sinama F, and Monceyron E. Experimental investigation of a solar cooling absorption system operating without any backup system under tropical climate. Energy Build, 2010; 42(6):774-782. doi:/10.1016/.2009.12.006.

[34] Mazloumi M, Naghashzadegan M, Javaherdeh K. Simulation of solar lithium bromide-water absorption cooling system with parabolic trough collector. Energy Convers Manage, 2008; 49(10):2820-2832. doi:/10.1016/.2008.03.014

[35] Monné, C., S. Alonso, F. Palacín, and L. Serra. Monitoring and simulation of an existing solar powered a bsorption cooling system in Zaragoza (Spain). Applied Thermal Engineering, 2011;31(1): 28-35. doi:/10.1016/.2010.08.002.

[36] Ortiz M., Barsun H., He H., Vorobieff P., and Mammoli A. Modeling of a solar-assisted HVAC system with thermal storage. Energy Build, 2010;42(4):500-509. doi:/10.1016/.2009.10.019.

[37] Pongtornkulpanich A., Thepa S., Amornkitbamrung M., and Butcher C. Experience with fully operational solar-driven 10-ton $\mathrm{LiBr} / \mathrm{H} 2 \mathrm{O}$ single-effect absorption cooling system in Thailand. Renew Energy, 2008; 33(5): 943- 949. doi:/10.1016/.2007.09.022.

[38] Praene JP, Marc O, Lucas F, Miranville F. Simulation and experimental investigation of solar absorption cooling system in Reunion Island." Applied Energy, 2011; 88(3): 831-839. doi:/10.1016/.2010.09.016.

[39] Prasartkaew B., and Kumar S. A low carbon cooling system using renewable energy resources and technologies. Energy Build 2010; 42(9):1453-1462. doi:/10.1016/.2010.03.015.

[40] Qu M., Yin H., and David H., Archer a solar thermal cooling and heating system for a building: experimental and model based performance analysis and design. Solar Energy, 2010; 84(2):166-182. doi:/10.1016/.2009.10.010.

[41] Rosiek, Sabina, and Francisco Javier Batlles Garrido. Performance evaluation of solar-assisted airconditioning system with chilled water storage (CIESOL building). Energy conversion and management, 2012; 55: 81-92. doi:/10.1016/.2011.10.025.

[42] Rosiek S., and Batlles F.J. Integration of the solar thermal energy in the construction: analysis of the solarassisted air-conditioning system installed in CIESOL building. Renew Energy, 2009; 34(6):1423-1431. doi:/10.1016/j.renene.2008.11.021.

[43] Said S.A.M., El-Shaarawi M.A.I., and Siddiqui, M.U. Alternative designs for a 24-h operating solarpowered absorption refrigeration technology. Int. J. of Refrigeration, 2012; 35: 1967-1977. doi:/10.1016/.2012.06.008. 
[44] Sarabia Escriva E.J., Lamas Sivila E.V., and Soto Frances V.M. Air conditioning production by a single effect absorption cooling machine directly coupled to a solar collector field. Application to Spanish climates. Solar Energy, 2011; 85: 2108-2121. doi:/10.1016/.2011.05.019.

[45] Sayegh, and Marderos Ara The solar contribution to air conditioning systems for residential buildings. Desalination,2007; 209: 171-176. doi:/10.1016/.2007.04.038.

[46] Syed A., Izquierdo M., Rodriguez P., Maidment G., Missenden J., Lecuona A. A novel experimental investigation of a solar cooling system in Madrid. Int. J. Refrigeration, 2005; 28(6):859-871. doi:/10.1016/.2005.01.007.

[47] Shekarchiana M., Moghavvemib M., Motasemic F., Mahliaa T.M.I. Energy savings and cost-benefit analysis of using compression and absorption chillers for air conditioners in Iran. Renewable Sustainable Energy, 2011;15:1950-1960. doi:/10.1016.2010.12.020.

[48] Thomas, Sébastien, and Philippe André. Dynamic simulation of a complete solar assisted air-conditioning system in an office building using TRNSYS. (2009). doi:/10.1016/j.renene.2008.11.021.

[49] Tsoutsos, Th, et al. Design of a solar absorption cooling system in a Greek hospital. Energy and Buildings, 2010;42(2): 265 -272.

[50] Ullah K.R., Saidur R., Ping H.W., Akikur R.K., and Shuvo N.H. A review of solar thermal refrigeration and cooling methods. Renew Sustain Energy Rev, 2013; 24: 499- 513. doi: /10.1016/.2013.03.024.

[51] Alirezaie, A., Hajmohammad, M. H., Ahangar, M. R. H., \& Esfe, M. H.. Price-performance evaluation of thermal conductivity enhancement of nanofluids with different particle sizes. Applied Thermal Engineering, 2018; 128: 373-380. doi:/10.1016/.2017.08.143.

[52] Esfe, M. H., Hajmohammad, H., Toghraie, D., Rostamian, H., Mahian, O., \& Wongwises, S. Multi-objective optimization of nanofluid flow in double tube heat exchangers for applications in energy systems. Energy, 2017; 137: 160-171. doi:/10.1016/.2017.06.104.

[53] Esfe, M. H., Saedodin, S., Biglari, M., \& Rostamian, H. An experimental study on thermophysical properties and heat transfer characteristics of low volume concentrations of Ag-water nanofluid. International Communications in Heat and Mass Transfer, 2016; 74: 91-97. doi:/10.1016/.2016.03.004.

[54] Esfe, M. H., Saedodin, S., Biglari, M., \& Rostamian, H. Experimental investigation of thermal conductivity of CNTs-Al2O3/water: a statistical approach. International Communications in Heat and Mass Transfer, 2015; 69:29-33. doi:/10.1016/2015.10.005.

[55] Bellos, E., Tzivanidis, C., Symeou, C., \& Antonopoulos, K. A. Energetic, exergetic and financial evaluation of a solar driven absorption chiller-A dynamic approach. Energy conversion and management, 2017; 137: 34-48. doi:/10.1016/.2017.01.041. 